\title{
AKUNTANSI KEBERLANUUTAN DAN PENGUKURAN KINERJA KEBERLANJUTAN UNIVERSITAS: MUNGKINKAH MENGAPLIKASIKAN AKUNTANSI KEBERLANJUTAN PADA INSTITUSI PENDIDIKAN TINGGI?
}

\author{
Putu Sukma Kurniawan, Made Arie Wahyuni \\ Program Studi Akuntansi, Universitas Pendidikan Ganesha \\ Jalan Udayana Nomor 11, Singaraja, Bali \\ email: putusukma@undiksha.ac.id
}

\begin{abstract}
This research aims to identify the ability of non-business organizations to implement the concept of sustainability accounting and to measure the organization's sustainability performance. This research takes the object at higher education institution and conducts analysis on the application of sustainability accounting concepts to universities. This study used a qualitative paradigm with data collection techniques using interview, observation, and document analysis method. To support the results of the study to be more comprehensive, this research also used the method of content analysis and literature review. To analyze the sustainability performance, this research used GASU method dan STARS Sytem. The results of this study found that non-business organizations can apply the concept of sustainability accounting and higher education institutions have very high capability to implement the concept of sustainability accounting.
\end{abstract}

Keywords: higher education institution, sustainability accounting

\begin{abstract}
ABSTRAK
Riset ini bertujuan untuk mengidentifikasi kemampuan organisasi nonbisnis untuk mengimplementasikan konsep akuntansi keberlanjutan dan mengukur kinerja keberlanjutan organisasi. Riset ini mengambil objek penelitian pada institusi pendidikan tinggi dan melakukan analisis mengenai pengukuran kinerja keberlanjutan pada universitas. Penelitian ini menggunakan paradigma kualitatif dengan teknik pengumpulan data menggunakan metode wawancara, observasi, dan analisis dokumen. Untuk mendukung hasil penelitian agar lebih komprehensif, riset ini juga menggunakan metode analisis konten dan literature review. Untuk menganalisis kinerja keberlanjutan, riset ini menggunakan metode GASU dan STARS System. Hasil riset ini menyimpulkan bahwa organisasi nonbisnis dapat mengaplikasikan konsep akuntansi keberlanjutan dan institusi pendidikan tinggi memiliki kemampuan yang sangat baik untuk menerapkan konsep akuntansi keberlanjutan.
\end{abstract}

Kata Kunci: akuntansi keberlanjutan, institusi pendidikan tinggi 


\section{PENDAHULUAN}

Konsep akuntansi keberlanjutan (sustainability accounting) kini menjadi paradigma baru dalam pengembangan sistem akuntansi di organisasi. Lamberton (2005) menyatakan bahwa konsep mengenai sustainability accounting muncul pada awal tahun 1990 dan perkembangan konsep ini sangat baik sampai dengan munculnya Sustainability Reporting Guidelines pada tahun 2002. Secara konseptual, konsep sustainability accounting dapat dimaknai sebagai alat atau teknik yang dapat dipergunakan oleh manajemen perusahaan untuk membantu perusahaan menjadi lebih sustainable. Kata "sustainable" disini bermakna bahwa terjadi transformasi dalam sistem akuntansi perusahaan dimana perusahaan beralih dari "akuntansi tradisional" menjadi akuntansi yang berfokus pada informasi ekonomi, informasi sosial, dan informasi lingkungan. Proses transformasi ini akan mengakibatkan perubahan pada setiap aktivitas bisnis perusahaan, misalnya keputusan manajemen tidak hanya berfokus pada dampak finansial perusahaan, namun juga berfokus pada dampak sosial dan dampak lingkungan.

Penerapan sustainability accounting memiliki banyak manfaat bagi organisasi. Konsep mengenai sustainability accounting tidak hanya berfokus pada nilai-nilai finansial perusahaan, namun juga berfokus pada strategi keberlanjutan dari perusahaan (sustainability strategy). Saat ini manajemen perusahaan telah banyak menerapkan konsep sustainability pada aktivitas bisnis perusahaan dan berkomitmen untuk melakukan pengungkapan mengenai dampak sosial dan ekonomi dari aktivitas bisnis perusahaan. Dengan menerapkan konsep sustainability accounting, maka manajemen perusahaan telah menghubungkan antara strategi bisnis perusahaan dengan kerangka kerja keberlanjutan (sustainability framework) dan proses ini akan membuat perusahaan tidak hanya berfokus pada dampak finansial saja, tetapi juga mempertimbangkan dampak sosial dan dampak lingkungan dari setiap keputusan bisnis yang dilakukan oleh manajemen perusahaan.

Konsep sustainability accounting kini menjadi isu menarik yang telah dibahas oleh para akuntan profesional. Permasalahan pada akuntansi konvensional adalah akuntansi konvensional tidak dapat mengukur mengenai aktivitas-aktivitas perusahaan yang tidak bersifat kuantitatif, namun aktivitas-aktivitas tersebut dapat menambah value bagi perusahaan. Contoh aktivitas tersebut adalah dampak aktivitas bisnis perusahaan pada komunitas sosial dan lingkungan hidup, hubungan perusahaan dengan pelanggan, komitmen yang kuat dari karyawan, dan motivasi tinggi manajemen perusahaan merupakan aktivitas perusahaan yang tidak dapat diukur dengan angka. Informasi-informasi ini merupakan informasi yang penting bagi pemangku kepentingan perusahaan dan konsep sustainability accounting dapat menyajikan jenis informasi ini dengan baik untuk selanjutnya informasi ini diungkapkan kepada pemangku kepentingan perusahaan. Peran dari pemangku kepentingan organisasi sangat menentukan kualitas dari implementasi konsep sustainability 
accounting pada sebuah organisasi. Riset dari Kaur \& Lodhia (2018) menunjukkan bahwa pemangku kepentingan perusahaan sangat berperan dalam penerapan sustainability accounting utamanya pada proses pelaporan informasi sosial dan lingkungan, pengembangan rencana strategik dan indikator keberlanjutan, pengukuran kinerja keberlanjutan, dan penyiapan laporan keberlanjutan organisasi.

Konsep sustainability accounting dapat diterapkan pada organisasi selain organisasi bisnis. Salah satu turunan dari praktek sustainability accounting adalah melakukan pengungkapan informasi keuangan, informasi sosial, dan informasi lingkungan dalam bentuk laporan keberlanjutan perusahaan (corporate sustainability reporting). Domingues et al. (2017) membahas mengenai praktek pengungkapan sustainability reporting pada organisasi sektor publik. Hasil penelitian Domingues et al. (2017) menunjukkan bahwa praktek implementasi pengungkapan informasi melalui corporate sustainability reporting dapat berdampak pada proses bisnis internal organisasi dan sangat dipengaruhi oleh peran dari pemangku kepentingan organisasi. Riset yang dilakukan oleh Farneti \& Guthrie (2009) meneliti mengenai praktek pengungkapan informasi melalui pelaporan keberlanjutan pada organisasi sektor publik di Australia. Riset ini menemukan bahwa pelaporan keberlanjutan yang dilakukan di dalam organisasi sektor publik sangat bermanfaat bagi seluruh pemangku kepentingan organisasi. Riset lain dilakukan oleh Adams et al. (2014) yang meneliti mengenai pengukuran dari kinerja keberlanjutan (sustainability performance) dari organisasi sektor publik. Riset dari Adams et al. (2014) menemukan bahwa pengukuran kinerja keberlanjutan pada organisasi sektor publik dapat berfokus pada aspek sustainability, environmental responsibility, dan social responsibility. Riset lain dari Adams (2013) bertujuan untuk menyusun konsep pelaporan keberlanjutan bagi universitas dan riset ini memiliki implikasi bagi kebijakan universitas dalam konteks penerapan konsep keberlanjutan. Adanya riset ini akan mengisi "ruang kosong" pada topik riset akuntansi keberlanjutan pada organisasi non-bisnis. Riset ini akan mencoba untuk memberikan pemahaman mengenai peluang diterapkannya konsep akuntansi keberlanjutan pada organisasi nonbisnis di Indonesia, khususnya pada institusi pendidikan tinggi.

Riset ini bertujuan untuk memberikan paradigma baru bahwa konsep akuntansi keberlanjutan dapat diterapkan pada organisasi non-bisnis. Konsep mengenai sustainability accounting saat ini telah banyak diterapkan, utamanya pada organisasi-organisasi dengan komitmen yang tinggi pada konsep keberlanjutan. Organisasi universitas publik merupakan salah satu contoh organisasi yang menerapkan sistem akuntansi dan sebuah universitas dapat menjadi pelopor dalam konteks implementasi konsep sustainability accounting. Riset ini berfokus pada pembuatan pedoman dalam implementasi sustainability accounting bagi organisasi non-bisnis, khususnya universitas. Penelitian ini diharapkan dapat memberikan kontribusi kepada kebijakan terkait dengan implementasi sustainability accounting pada organisasi-organisasi di Indonesia. Beberapa organisasi yang menyusun sistem akuntansi, misalnya SASB (Sustainability Accounting Standard Board), telah merilis standar atau pedoman 
mengenai implementasi konsep sustainability accounting untuk organisasi bisnis dan organisasi non-bisnis. Adanya standar atau pedoman mengenai sustainability accounting ini menunjukkan bahwa semakin banyak organisasi yang memiliki komitmen untuk menerapkan konsep sustainability accounting pada aktivitas organisasi. Kebijakan mengenai implementasi sustainability accounting tidak hanya disusun bagi organisasi bisnis saja, namun nantinya kebijakan ini dapat dipergunakan pada organisasi non-bisnis. Salah satu hal yang dapat dilakukan agar proses implementasi konsep akuntansi keberlanjutan banyak diterapkan oleh organisasi adalah dengan mengeluarkan pedoman atau standar mengenai implementasi konsep akuntansi keberlanjutan.

\section{METODE PENELITIAN}

Penelitian ini didasarkan pada sudut pandang atau paradigma kualitatif. Desain penelitian ini mengacu pada desain riset yang dilakukan oleh Kaur \& Lodhia (2018) yang menggunakan desain penelitian studi kasus. Desain penelitian studi kasus pada riset ini dipergunakan untuk mengembangkan konsep implementasi sustainability accounting pada objek penelitian. Penelitian ini juga mempergunakan metode Graphical Assessment of Sustainability in Universities (GASU) yang dikembangkan oleh Lozano (2006) untuk menilai tingkat penerapan konsep keberlanjutan pada objek penelitian. Kerangka berpikir dalam penelitian ini dibentuk melalui pemahaman bahwa konsep sustainability accounting dapat diterapkan pada semua organisasi, baik organisasi bisnis maupun organisasi non-bisnis. Dengan menggunakan logika ini, maka dapat dipahami bahwa setiap organisasi memiliki kemampuan untuk mengimplementasikan konsep sustainability accounting pada aktivitas organisasi. Proses implementasi sustainability accounting tidak dipahami dengan melakukan penggantian total pada sistem akuntansi yang telah diterapkan oleh perusahaan. Proses implementasi sustainability accounting pada sebuah organisasi harus memperhatikan (1) sistem akuntansi yang saat ini berlaku di dalam organisasi dan (2) karakteristik dari organisasi. Kerangka berpikir riset ini juga didasarkan pada konsep dari riset Adams et al. (2014) yang menyatakan bahwa semua organisasi dapat mengimplementasikan konsep sustainability accounting pada aktivitas bisnis organisasi dan riset dari Lange \& Kerr (2013) yang menyatakan bahwa terdapat beberapa proses akuntansi di lingkungan pendidikan tinggi yang justru menghambat penerapan konsep keberlanjutan di universitas.

Penelitian ini dilakukan di Universitas Pendidikan Ganesha, Bali dengan berfokus pada pengukuran kinerja keberlanjutan universitas dan kemungkinan adopsi akuntansi keberlanjutan pada universitas. Beberapa alasan penelitian ini dilakukan di Universitas Pendidikan Ganesha, yaitu (1) peneliti memiliki akses data untuk melakukan wawancara, observasi, dan analisis dokumen terkait dengan sistem akuntansi yang sekarang diterapkan, (2) tersedia pedoman untuk mengukur kinerja keberlanjutan organisasi yang sesuai dengan karakteristik universitas, dan (3) Universitas Pendidikan Ganesha memiliki daya dukung yang sangat baik untuk menerapkan konsep sustainability accounting. Alasan lainnya yang membuat peneliti memilih 
universitas sebagai objek penelitian tidak lain adalah motivasi peneliti untuk menyusun konsep sustainability accounting pada organisasi sektor pendidikan. Selama ini proses implementasi atau penerapan konsep sustainability accounting selalu berfokus pada organisasi bisnis (perusahaan swasta) sehingga riset ini mengambil ruang lain dengan mencoba untuk menyusun konsep implementasi sustainability accounting pada organisasi non-bisnis (universitas). Universitas memiliki peranan yang penting untuk turut mengembangkan praktek-praktek akuntansi keberlanjutan dan proses ini akan sangat membantu bagi organisasi non-bisnis lain untuk mengimplementasikan konsep akuntansi keberlanjutan di dalam aktivitas organisasi.

Metode pengumpulan data pada riset ini mengacu pada metode yang dipergunakan pada riset Kaur \& Lodhia (2018). Riset Kaur \& Lodhia (2018) mempergunakan metode interview dan analisis dokumen untuk mendapatkan data penelitian. Riset ini menggunakan beberapa metode untuk pengumpulan data. Metode pengumpulan data yang dipergunakan, yaitu

1. Metode wawancara

Proses wawancara dilakukan terhadap pihak-pihak di dalam universitas yang memahami mengenai sistem akuntansi yang sedang berjalan dan memahami mengenai rencana pengembangan kampus di masa depan. Narasumber wawancara dalam riset ini adalah Wakil Rektor II yang memahami mengenai masalah administrasi dan keuangan, Kepala Biro Umum dan Keuangan yang memahami mengenai praktek akuntansi di dalam universitas, Kepala Bagian Divisi Akuntansi yang memahami mengenai proses akuntansi di dalam kegiatan universitas, dan pegawai pada bagian keuangan dan bagian akuntansi. Proses penentuan narasumber wawancara akan didasarkan pada metode atau teknik snowball dimana narasumber sebelumnya akan menjadi petunjuk siapa narasumber berikutnya yang tepat untuk diwawancarai demi mendapatkan data yang komprehensif.

2. Metode observasi

Proses observasi pada riset ini dipergunakan untuk memahami proses akuntansi yang saat ini digunakan di lingkungan Universitas Pendidikan Ganesha. Observasi juga dilakukan di jurusan atau fakultas yang terdapat di lingkungan universitas untuk memahami proses akuntansi. Kegiatan observasi juga dilakukan untuk melihat aktivitas universitas dalam bidang sosial dan lingkungan (bidang keberlanjutan). Metode observasi juga dipergunakan untuk melihat aktivitas-akvititas di dalam universitas yang sesuai dengan pedoman penilaian kinerja keberlanjutan. Metode observasi ini didasarkan pula pada riset Petcharat \& Mula (2012) yang menggunakan penelitian kualitatif untuk melakukan pendekatan pada analisis data.

3. Metode analisis dokumen

Metode pengumpulan data dengan analisis dokumen dilakukan dengan metode content analysis untuk mencari informasi-informasi yang diperlukan dari dokumen yang tersedia sebagai data. Dokumen-dokumen yang dikumpulkan dianalisis untuk mendapatkan data penelitian. Untuk melakukan konfirmasi mengenai data yang terdapat pada dokumen, 
maka dilakukan proses wawancara dan observasi untuk mengecek keabsahan data. Dokumen-dokumen yang dianalisis pada riset ini adalah dokumen prosedur atau pedoman yang berhubungan dengan kinerja keberlanjutan dari universitas.

Proses penilaian kinerja keberlanjutan dari objek penelitian dengan mempergunakan Graphical Assessment of Sustainability in Universities (GASU) yang dikembangkan oleh Lozano (2006) dan menggunakan STARS system yang dikembangkan oleh AASHE. Riset ini menggunakan pedoman GASU karena pedoman GASU telah menjadi pedoman utama yang dapat dipergunakan untuk menilai kinerja keberlanjutan dari sebuah universitas. Pedoman GASU merupakan pelopor sebagai alat untuk mengukur kinerja keberlanjutan universitas. Hasil dari pengukuran menggunakan model GASU akan dibandingkan dengan hasil pengukuran menggunakan STARS system. Argumen riset ini menggunakan STARS system adalah (1) STARS system memberikan kerangka kerja yang jelas untuk memahami kinerja keberlanjutan, khususnya pada organisasi pendidikan tinggi, (2) hasil pengukuran kinerja dapat diperbandingkan dengan beberapa kinerja keberlanjutan dari organisasi pendidikan yang lain, dan (3) memberikan masukan dan saran bagi pengembangan kinerja keberlanjutan organisasi di masa depan. Tahapan ini nantinya dapat membantu dalam proses identifikasi kinerja keberlanjutan dari Universitas Pendidikan Ganesha dan akan memberikan gambaran kualitas kinerja keberlanjutan yang telah dijalankan.

\section{HASIL DAN PEMBAHASAN}

3.1. Standar atau Pedoman Implementasi Sustainability Accounting pada Organisasi Bisnis dan Organisasi Non-Bisnis

SIGMA Project (2003) menyatakan bahwa konsep sustainability accounting pada awalnya merupakan perluasan dari kerangka kerja akuntansi keuangan. Pendapat ini semakin memperkuat bahwa pada dasarnya konsep sustainability accounting merupakan konsep turunan dari konsep akuntansi keuangan. Di Inggris, konsep sustainability accounting disusun oleh badan regulasi dan dewan akuntansi professional (SIGMA Project, 2003). Pada awalnya pedoman mengenai konsep sustainability accounting di Inggris terdapat pada UK Generally Accepted Accounting Practice (UK GAAP). Pedoman mengenai penerapan konsep sustainability accounting pada lingkup aktivitas organisasi sektor pendidikan disusun oleh Lozano (2006) yang menyusun sebuh metode untuk menilai kemampuan sebuah institusi pendidikan untuk menerapkan konsep keberlanjutan. Metode ini disebut dengan Graphical Assessment of Sustainability in Universities (GASU). Metode GASU ini dipergunakan untuk memfasilitasi analisis penerapan konsep keberlanjutan pada aktivitas universitas dan sebagai alat pembanding kinerja keberlanjutan antar universitas.

Konsep sustainability accounting nampaknya menjadi perhatian dari pemerintah di negara yang berkomitmen untuk menerapkan konsep sustainability accounting. Panduan mengenai akuntansi lingkungan disusun oleh Kementerian Lingkungan pemerintah Jepang dan dirilis pada tahun 2005. Panduan akuntansi lingkungan (Environmental Accounting Guidelines) mengatur mengenai konsep akuntansi lingkungan dari sudut pandang pemerintah, mengatur mengenai identifikasi jenis-jenis biaya lingkungan, dan 
memberikan pedoman mengenai pengukuran biaya-biaya lingkungan tersebut. Hadirnya panduan mengenai akuntansi lingkungan ini sangat membantu manajemen perusahaan dan pimpinan organisasi di Jepang untuk melakukan identifikasi dan pengukuran biaya-biaya sosial yang terkait dengan aktivitas perusahaan atau aktivitas organisasi. Panduan mengenai implementasi konsep sustainability accounting berikutnya disusun oleh Pemerintah Selandia Baru yang merilis panduan tentang identifikasi dan analisis biaya sosial. Panduan tersebut dinamakan Guide to Social Cost Benefit Analysis dan dikeluarkan pada tahun 2015. Panduan ini sangat penting bagi pimpinan organisasi untuk melakukan identifikasi dan pengukuran terkait dengan biaya sosial yang berhubungan aktivitas organisasi.

\subsection{Implementasi Sustainability Accounting pada Organisasi Non- Bisnis}

Konsep mengenai sustainability accounting tidak hanya dapat diterapkan pada organisasi bisnis saja, tetapi organisasi non-bisnis dapat pula mengimplementasikan konsep sustainability accounting. Riset mengenai implementasi konsep sustainability accounting dilakukan oleh Adams et al. 2014) yang menyusun sebuah konsep pengukuran kinerja keberlanjutan bagi organisasi sektor publik di Australia. Riset ini sangat bermanfaat bagi organisasi-organisasi sektor publik yang ingin melakukan pengukuran kinerja keberlanjutan organisasi. Riset lain tentang implementasi sustainability accounting pada organisasi non-bisnis dilakukan oleh McNicholas et al. (2016) yang meneliti mengenai praktek sustainability accounting pada organisasi sektor publik di Malaysia. Riset McNicholas et al. (2016) menemukan bahwa organisasi sektor publik di Malaysia mengembangkan sebuah sistem pelaporan untuk meningkatkan kinerja keberlanjutan dan implementasi konsep sustainability accounting akan meningkatkan proses pengambilan keputusan seluruh pemangku kepentingan organisasi. Riset Kaur \& Lodhia (2018) menunjukkan bahwa implementasi konsep sustainability accounting pada organisasi non-bisnis sangat dipengaruhi oleh peran dari pemangku kepentingan organisasi. Peran pemangku kepentingan organisasi berkorelasi positif dengan kualitas implementasi sustainability accounting di dalam organisasi. Riset lain dari Adams (2013) menyajikan sebuah konsep mengenai cara untuk meningkatkan kinerja keberlanjutan dari sebuah universitas dan berfokus untuk mengintegrasikan konsep keberlanjutan (kinerja ekonomi, kinerja sosial, dan kinerja lingkungan) ke dalam aktivitas universitas. Organisasi-organisasi yang berada pada sektor publik dan organisasi non-profit saat ini memiliki permintaan yang tinggi untuk menerapkan konsep keberlanjutan dari para pemangku kepentingan organisasi dan pemangku kepentingan cenderung untuk memonitor organisasi agar menjalankan kinerja keberlanjutan pada aktivitas organisasi (Farneti \& Guthrie, 2009).

\subsection{Identifikasi Kinerja Keberlanjutan dari Objek Penelitian dengan Mempergunakan Graphical Assessment of Sustainability in Universities (GASU) dan STARS System}

Tahapan riset ini bertujuan untuk melakukan penilaian terhadap kinerja keberlanjutan (sustainability performance) dari Universitas Pendidikan Ganesha. Tahapan penilaian ini sangat penting untuk melihat apakah performa 
keberlanjutan dari Universitas Pendidikan Ganesha berada pada level yang baik atau tidak. Hasil dari tahapan ini akan memberikan evaluasi bagi pihak universitas tentang kinerja keberlanjutan yang selama ini telah dilakukan oleh universitas. Hasil dari tahapan ini juga penting sebagai dasar dalam konteks pengungkapan informasi finansial dan informasi non-finansial universitas pada laporan keberlanjutan universitas. Berdasarkan teori, jika sebuah oganisasi memiliki kinerja keberlanjutan yang baik, maka organisasi tersebut akan cenderung untuk semakin memperluas pengungkapan informasi finansial dan informasi non-finansial pada laporan keberlanjutan organisasi. Proses identifikasi dari kinerja keberlanjutan universitas ini akan mempergunakan dua indikator yaitu Graphical Assessment of Sustainability in Universities yang dikembangkan oleh Lozano (2006) dan STARS system (Sustainability Tracking, Assessment \& Rating System) yang dikembangkan oleh AASHE (The Association for the Advancement of Sustainability in Higher Education). Lozano (2006) menyatakan bahwa indikator GASU yang telah dikembangkan akan memberikan proses penilaian yang sistematik dan hasilnya dapat dipergunakan sebagai dasar untuk penyusunan laporan keberlanjutan universitas. Secara umum, indikator penilaian kinerja keberlanjutan dari GASU memiliki 5 ukuran kinerja, yaitu (1) profile, (2) economic, (3) environmental, (4) social, dan (5) educational.

Tabel 1. Indikator Penilaian dalam GASU

\begin{tabular}{ll}
\hline \multicolumn{1}{c}{ Dimension } & Category \\
\hline Profile & Strategy and analysis \\
& Organisational profile \\
& Governance, commitments, and engagement \\
& Management approach and performance \\
Economic & Earket presence \\
& Indirect Economic Impacts \\
Environmental & Materials \\
& Energy \\
& Water \\
& Biodiversity \\
& Emissions, effluents, and waste \\
& Product and services \\
& Environmental compliance \\
& Transport \\
Labour practices and decent work \\
Human rights \\
Society \\
Product responsibility \\
Curriculum \\
Research \\
Service
\end{tabular}

Sumber : (Lozano, 2006)

Untuk melakukan analisis dengan menggunakan GASU, riset ini mempergunakan data sekunder dari laman resmi universitas dan laporan atau 
dokumen terkait yang telah dipublikasikan oleh universitas. Berdasarkan pedoman GASU, nilai-nilai indikator kinerja adalah 43 untuk profil, 9 untuk bidang ekonomi, 30 untuk bidang lingkungan, 40 untuk bidang sosial, 29 untuk bidang pendidikan, dan 23 untuk bidang interlinked issues and dimensions. Setiap indikator-indikator pada pedoman GASU dianalisis dengan menggunakan pedoman berikut:

- Nilai 0 diberikan jika informasi terkait indikator tidak ada atau tidak ditemukan dalam laporan universitas

- Nilai 1 diberikan jika informasi menyatakan poor performance. Informasi bersifat umum dan tidak mendetail.

- Nilai 2 diberikan jika informasi menyatakan regular/fair performance. Informasi bersifat umum, masih membahas setengah dari topik, dan belum mendetail

- Nilai 3 diberikan jika informasi menyatakan good performance. Informasi sudah bersifat mendetail dan sudah termasuk isu yang dibahas

- Nilai 4 diberikan jika informasi menyatakan excellent performance. Informasi yang disajikan sudah lengkap dan mendetail untuk satu indikator.

Berdasarkan pedoman GASU dan pedoman penilaian, maka dilakukan analisis kinerja keberlanjuan universitas. Hasil analisis tersebut disajikan pada tabel di bawah ini.

Tabel 2. Analisis Kinerja Keberlanjutan Berdasarkan Metode GASU

\begin{tabular}{lcc}
\hline Kinerja Keberlanjutan & Persentase Informasi & Rasio Informasi \\
\hline Profile & $41,9 \%$ & 0,419 \\
Economic & $22 \%$ & 0,22 \\
Environmental & $40 \%$ & 0,4 \\
Social & $80 \%$ & 0,8 \\
Educational & $62 \%$ & 0,62 \\
Inter-linking & $39 \%$ & 0,39 \\
and dimensions & & \\
\hline
\end{tabular}

Sumber : Data diolah

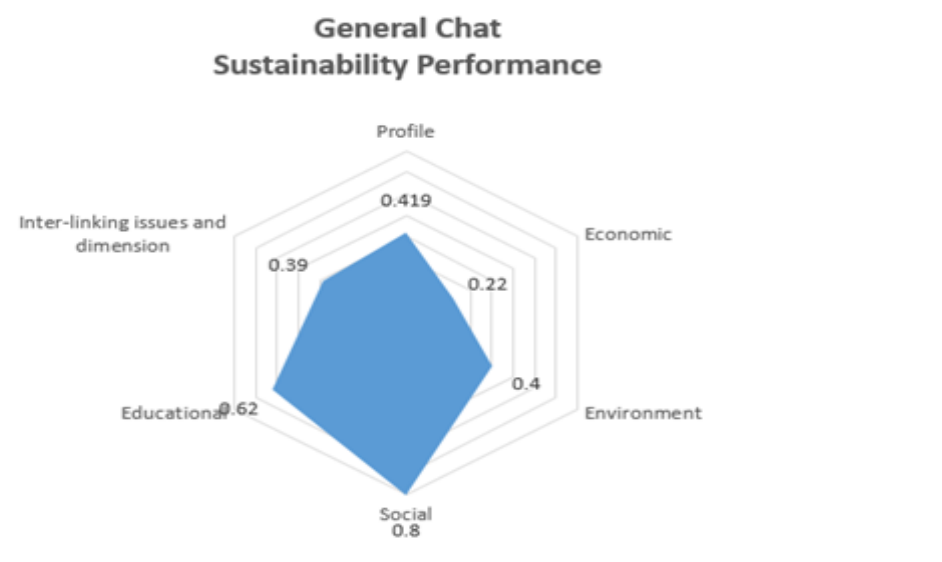

Gambar 1. Hasil analisis kinerja keberlanjutan GASU 
Berdasarkan general chart yang dihasilkan dari analisis, dapat diambil sebuah simpulan bahwa pada dasarnya Universitas Pendidikan Ganesha telah memiliki kinerja keberlanjutan yang baik. Kinerja keberlanjutan universitas yang baik ditunjukkan pada bidang sosial dan bidang pendidikan, khususnya pada penciptaan praktek lingkungan kerja yang sehat, pengakuan pada hak asasi manusia, pengembangan kurikulum, dan riset terkait topik keberlanjutan. Hal ini sejalan dengan karakterisik bisnis dari universitas yang lebih banyak memiliki kinerja pada bidang sosial. Untuk meningkatkan kinerja keberlanjutan di masa depan, universitas harus berfokus untuk meningkatkan kinerja pada bidang lingkungan.

Ukuran pengukuran kinerja kebelanjutan yang berikutnya dipergunakan dalam riset ini adalah pengukuran kinerja STARS System yang dikembangkan oleh AASHE. Pengukuran kinerja dengan STARTS System berfokus untuk melakukan pengukuran kinerja keberlanjutan pada institusi pendidikan tinggi. Indikator-indikator pengukuran kinerja pada STARS System memang ditujukan untuk melakukan penilaian kinerja keberlanjutan untuk organisasi pada sektor pendidikan. Dalam riset ini, pengukuran kinerja keberlanjutan pada Universitas Pendidikan Ganesha menggunakan checklist yang disediakan dari pengukuran kinerja STARS System. Secara umum, terdapat lima kategori pengukuran kinerja keberlanjutan, yaitu (1) academics (AC), (2) engagement (EN), (3) operations (OP), (4) planning and administration (PA), dan (5) innovation and leadership (IN). Kategori academics menjelaskan indikator-indikator keberlanjutan dalam konteks proses pendidikan dan pengajaran di universitas. Kategori engagement menjelaskan indikator keberlanjutan dalam konteks hubungan universitas dengan mahasiswa dan hubungan pihak universitas dengan komunitas sosial. Kategori operations menjelaskan indikator-indikator keberlanjutan dalam konteks operasional universitas dan kategori planning and administration menjelaskan tentang indikator dalam konteks perencanaan dan administrasi universitas. Kategori innovation and leaderhip menjelaskan tentang indikator keberlanjutan dalam konteks inovasi dan kepemimpinan publik yang dilakukan oleh universitas. Beberapa kategori ini akan dibagi lagi menjadi beberapa sub kategori yang akan menunjukkan indikator-indikator kinerja keberlanjutan universitas.

Untuk melakukan analisis terhadap kinerja keberlanjutan Universitas Pendidikan Ganesha, maka riset ini menggunakan laporan dan dokumen yang dirilis oleh universitas. Laporan dan dokumen yang dianalisis adalah laporan tahunan universitas dan fakultas dan laporan serta dokumen lain yang terkait. Metode content analysis dipergunakan pada tahapan ini dengan melihat isi laporan universitas kemudian menganalisis informasi tersebut apakah terdapat pada checklist indikator kinerja keberlanjutan. Analisis akan dilakukan berdasarkan kategori dan indikator kinerja keberlanjutan.

Berdasarkan tabel 2, dapat diketahui bahwa rasio terbesar terdapat pada kategori akademik. Ini menunjukkan bahwa universitas telah memiliki kinerja keberlanjutan yang baik pada bidang pendidikan, khususnya pada pemberian materi tentang konsep keberlanjutan dan riset dan publikasi yang berkaitan dengan topik keberlanjutan. Universitas juga telah memiliki kinerja keberlanjutan yang baik pada bidang perencanaan dan administrasi, khususnya pada penciptaan lingkungan kerja yang baik. Hasil analisis ini menujukkan kesamaan dengan hasil analisis dari pedoman GASU dimana 
universitas belum memiliki kinerja keberlanjutan yang baik pada bidang perikatan dan bidang operasi. Universitas belum memiliki program pelatihan yang berkaitan dengan konsep keberlanjutan dan pada bidang operasi, universitas belum memiliki pedoman dalam pengelolaan limbah.

Tabel 2. Analisis Kinerja Keberlanjutan Berdasar STARS System

\begin{tabular}{lcc}
\hline \multicolumn{1}{c}{ Kategori } & Persentase Informasi & Rasio Informasi \\
\hline Academics & $63,6 \%$ & 0,636 \\
Engagement & $28,6 \%$ & 0,286 \\
Operations & $35,3 \%$ & 0,353 \\
Planning and & $45,5 \%$ & 0,455 \\
Administration & & \\
\hline
\end{tabular}

Sumber : Data diolah

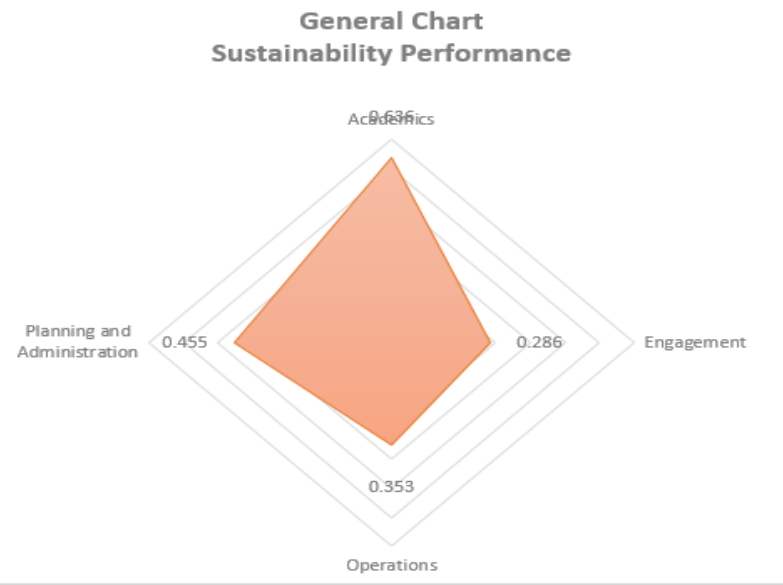

Gambar 2. Hasil analisis kinerja keberlanjutan STARS System

Hasil dari analisis content analysis ini dapat dipergunakan untuk menilai dan melakukan evaluasi terhadap kinerja keberlanjutan dari Universitas Pendidikan Ganesha. Pada bidang akademik, universitas telah memiliki kurikulum yang memasukkan materi terkait dengan keberlanjutan. Mata kuliah yang terkait dengan topik keberlanjutan adalah Akuntansi Sosial dan Lingkungan yang terdapat pada program studi Akuntansi S1. Dukungan terhadap topik keberlanjutan juga diwujudkan dalam bentuk riset dengan telah dilakukannya riset-riset yang berhubungan dengan konsep keberlanjutan. Konsep keberlanjutan belum banyak diwujudkan dalam aktivitas operasional universitas. Universitas belum memiliki kebijakan dan prosedur terkait dengan pengolahan limbah dan kebijakan penggunaan energi. Meskipun demikian, universitas memiliki kinerja keberlanjutan yang sangat baik dalam bidang sosial. Universitas telah menjalin kerjasama dengan desa binaan dan komunitas sosial. Universitas juga telah memiliki perhatian dan komitmen yang kuat terhadap lingkungan kerja dan kesehatan dan keselamatan kerja dari karyawan.

Riset dari Richardson \& Kachler (2016) membuat dua kelompok ukuran dari kinerja keberlanjutan universitas. Kelompok pertama adalah high performance dimana kelompok ini adalah universitas yang memiliki kinerja 
keberlanjutan yang tinggi. Universitas-universitas yang berada pada kelompok ini akan cenderung untuk melaporkan kinerja keberlanjutan melalui laporan keberlanjutan universitas. Kelompok kedua adalah low performance dimana kelompok ini adalah universitas-universitas yang memiliki kinerja keberlanjutan yang rendah. Richardson \& Kachler (2016) berhipotesis bahwa berdasarkan teori legitimasi, universitas yang berada pada kelompok ini akan tetap untuk melaporkan kinerja keberlanjutannya dengan tujuan untuk mengurangi reaksi negatif dari kelompok pemangku kepentingan universitas dan menutupi kinerja yang rendah dengan melaporkan informasi palsu pada laporan keberlanjutan universitas. Berdasarkan hasil content analysis dan kesimpulan dari riset Richardson \& Kachler (2016), riset ini mengambil simpulan bahwa pada dasarnya Universitas Pendidikan Ganesha telah memiliki kinerja keberlanjutan yang cukup. Universitas memiliki kinerja keberlanjutan yang baik pada bidang pendidikan dan bidang sosial. Perlu usaha yang lebih tinggi lagi untuk meningkatkan kinerja keberlanjutan universitas pada bidang lingkungan. Kinerja keberlanjutan Universitas Pendidikan Ganesha berada pada posisi middle performance (antara high performance dan low performance). Jika pihak universitas ingin meningkatkan kinerja keberlanjutan, maka universitas harus meningkatkan kinerja pada poin-poin yang belum diraih.

\subsection{Pembahasan}

Hasil analisis kinerja keberlanjutan dengan menggunakan pedoman GASU dan STARS System menunjukkan bahwa Universitas Pendidikan Ganesha memiliki kemampuan yang cukup untuk mengimplementasikan konsep akuntansi keberlanjutan pada aktivitas organisasi. Untuk mengimplementasikan konsep akuntansi keberlanjutan pada organisasi, maka terlebih dahulu dilakukan penilaian kinerja keberlanjutan untuk menilai kesanggupan organisasi menjalankan konsep akuntansi keberlanjutan. Penilaian kinerja keberlanjutan sangat penting dilakukan untuk melihat indikator-indikator kinerja keberlanjutan yang sudah dilakukan. Secara umum, kegiatan universitas termasuk dalam bidang pendidikan dan aktivitas dalam bidang ini cenderung untuk tidak menghasilkan dampak atau eksternalitas negatif kepada kelompok pemangku kepentingan perusahaan. Fakta ini tentu berbanding terbalik dengan perusahaan-perusahaan yang tergabung dalam industri, misalnya industri pertambangan dan manufaktur, yang aktivitas bisnisnya dapat menghasilkan dampak negatif kepada komunitas sosial dan lingkungan. Tidak adanya dampak buruk kepada komunitas sosial dan lingkungan dari kegiatan universitas dibuktikan dengan tingginya kinerja keberlanjutan universitas pada indikator kinerja lingkungan dan indikator kinerja sosial. Hasil ini mengindikasikan bahwa sebuah universitas atau institusi pendidikan tinggi dapat mengimplementasikan konsep akuntansi keberlanjutan dengan berfokus pada kinerja lingkungan dan kinerja sosial. Untuk meningkatkan kinerja pada bidang lingkungan, universitas dapat melakukan pencatatan dan pengukuran terhadap biaya lingkungan yang terdapat di dalam aktivitas internal universitas. Adanya pengakuan terhadap biaya lingkungan ini akan menunjukkan komitmen yang tinggi dari pihak universitas terhadap peningkatan kinerja keberlanjutan universitas. 
Penerapan akuntansi keberlanjutan yang berikutnya dapat dilakukan oleh universitas adalah melakukan pelaporan informasi finansial dan informasi nonfinansial melalui laporan keberlanjutan universitas. Selama ini Universitas Pendidikan Ganesha telah melakukan pengungkapan informasi yang sangat baik kepada publik. Hasil wawancara dengan pimpinan universitas mendukung fakta ini yang menyatakan bahwa

"Pihak universitas berkomitmen untuk melakukan pengungkapan informasi publik. Kami sangat tertarik dengan konsep akuntansi keberlanjutan dan nampaknya konsep pelaporan keberlanjutan universitas dapat kami pergunakan sebagai sarana komunikasi kinerja atau capaian universitas kepada publik."

Hasil wawancara ini menunjukkan bahwa pada dasarnya pihak universitas memiliki komitmen yang tinggi untuk menerapkan konsep keberlanjutan dan muaranya adalah adanya pelaporan keberlanjutan yang dilakukan oleh universitas. Pihak universitas menyadari bahwa pelaporan keberlanjutan merupakan sarana yang tepat bagi universitas untuk membangun komunikasi yang baik dengan seluruh pemangku kepentingan universitas. Riset dari Ceulemans et al. (2015) meneliti tentang pentingnya pengungkapan informasi melalui laporan keberlanjutan universitas untuk memperkuat hubungan antara universitas dengan publik dan hubungannya dengan pengambilan keputusan yang dilakukan oleh pemangku kepentingan universitas. Informasi finansial dan informasi non-finansial yang diungkapkan oleh universitas akan menjadi dasar atau referensi dalam proses pengambilan keputusan oleh pemangku kepentingan. Semaking tinggi kualitas informasi yang diungkapkan, maka akan berbanding lurus dengan kualitas pengambilan keputusan yang dibuat oleh pemangku kepentingan universitas.

Untuk menjalankan konsep akuntansi keberlanjutan, pihak universitas memerlukan dukungan dari seluruh pemangku kepentingan universitas. Riset dari Kaur \& Lodhia (2018) menyatakan bahwa proses stakeholder engagement sangat diperlukan oleh organisasi agar mampu menjalankan konsep akuntansi keberlanjutan, termasuk nantinya melaksanakan pengungkapan informasi finansial dan informasi non-finansial dalam laporan keberlanjutan organisasi. Beberapa riset terdahulu telah menyatakan bahwa universitas mampu untuk menyusun dan melaporkan laporan keberlanjutan. Riset dari An et al. (2017) meneliti tentang tren pelaporan keberlanjutan pada universitas di Selandia Baru dan menemukan bahwa informasi terbanyak yang diungkapkan adalah informasi mengenai kinerja lingkungan kemudian selanjutnya adalah informasi kinerja ekonomi dan informasi kinerja sosial.

Penerapan dari konsep akuntansi keberlanjutan juga secara langsung dapat mempengaruhi proses pendidikan dan pengajaran di dalam universitas. Riset dari Owen (2013) meneliti tentang dampak dari proses pelaporan terintegrasi (integrated reporting) yang dilakukan oleh universitas terhadap kurikulum akuntansi. Riset dari Owen (2013) didukung oleh riset yang dilakukan oleh Botes et al. (2014) yang meneliti apakah pendidikan akuntansi di Selandia Baru sudah mengandung konsep keberlanjutan atau tidak. Riset dari Botes et al. (2014) menyimpulkan bahwa pendidikan akuntansi belum memiliki konsep keberlanjutan dan seluruh pemangku kepentingan berpendapat bahwa konsep keberlanjutan harus dimasukkan di dalam 
pendidikan akuntansi. Tugas ini merupakan tugas dari sebuah universitas dan akan menjadi bagian dari kinerja keberlanjutan universitas.

Riset ini juga mengidentifikasi hambatan dan tantangan dalam proses implementasi konsep akuntansi keberlanjutan di universitas. Identifikasi yang pertama menemukan bahwa belum adanya standar atau pedoman dalam penerapan konsep akuntansi keberlanjutan untuk universitas merupakan tantangan dalam penerapan konsep ini. Beberapa organisasi yang peduli dalam pengembangan konsep akuntansi keberlanjutan, misalnya SASB, telah mengeluarkan panduan dan pedoman untuk proses implementasi akuntansi keberlanjutan pada institusi pendidikan tinggi. Permasalahan dapat muncul ketika panduan atau pedoman ini tidak sesuai dengan karakteristik institusi pendidikan tinggi di Indonesia. Perbedaan ini akan mengakibatkan standar atau pedoman tersebut tidak dapat diaplikasikan untuk universitas di Indonesia. Identifikasi berikutnya menemukan bahwa kelompok pemangku kepentingan universitas belum menaruh perhatian yang serius agar universitas menerapkan konsep akuntansi keberlanjutan. Beberapa riset yang telah dilakukan, misalnya Amran \& Keat Ooi (2014), Bradford et al. (2016), dan O'Dochartaigh (2017), menemukan bahwa adanya tekanan atau permintaan dari pemangku kepentingan organisasi agar organisasi mengungkapkan informasi dalam laporan keberlanjutan menjadi salah satu faktor krusial yang mendorong manajemen organisasi untuk menyusun laporan keberlanjutan. Dengan kata lain, tekanan atau permintaan dari pemangku kepentingan organisasi merupakan faktor penting dari eksternal organisasi agar manajemen dapat melakukan penyusunan laporan keberlanjutan. Jika setidaknya kedua hambatan dan tantangan ini dapat diminimalisasi, maka peluang universitas untuk mengimplementasikan konsep akuntansi keberlanjutan akan semakin besar.

\section{PENUTUP}

Penelitian ini menyimpulkan bahwa organisasi non-bisnis dapat mengimplementasikan akuntansi keberlanjutan pada aktivitas organisasi. Hasil pengukuran kinerja keberlanjutan menunjukkan bahwa institusi pendidikan tinggi memiliki kinerja keberlanjutan yang sangat baik (utamanya pada kinerja sosial dan kinerja lingkungan) dan hasil ini tentu saja dapat dipergunakan sebagai dasar atau argumentasi untuk mengimplementasikan konsep akuntansi keberlanjutan pada sebuah universitas. Berdasarkan hasil riset yang telah didapat, penelitian ini dapat memberikan saran baik bagi pihak universitas maupun bagi pemangku kepentingan dari universitas. Saran dari riset ini berfokus untuk mendorong implementasi konsep dan praktek dari akuntansi keberlanjutan di organisasi sektor pendidikan dan mendukung adanya penyusunan pedoman resmi tentang implementasi konsep akuntansi keberlanjutan bagi universitas publik. Saran yang dapat diberikan dari riset ini, yaitu

1. Bagi Universitas Pendidikan Ganesha

Hasil riset ini menunjukkan bahwa Universitas Pendidikan Ganesha memiliki kemampuan dan kapabilitas yang tinggi untuk melakukan implementasi konsep dan praktek dari akuntansi keberlanjutan. Di masa depan, pimpinan universitas harus terus berupaya untuk meningkatkan kinerja lingkungan universitas. Peningkatan kinerja lingkungan 
universitas akan menunjukkan komitmen dari pimpinan universitas untuk menjalankan aktivitas-aktivitas universitas berdasarkan konsep keberlanjutan. Saat ini, Universitas Pendidikan Ganesha telah memiliki kinerja keberlanjutan yang baik pada konteks pendidikan dan penelitian. Di masa depan, universitas dapat meningkatkan kinerja keberlanjutannya pada indikator-indikator keberlanjutan yang lain. Untuk mendukung dalam konteks peningkatkan kinerja keberlanjutan universitas, pihak manajemen universitas dapat membentuk sebuah unit atau bagian yang bertugas khusus untuk mengembangkan dan menerapkan konsep keberlanjutan di dalam aktivitas universitas. Adanya unit atau bagian yang berfokus pada penerapan konsep keberlanjutan di dalam struktur organisasi universitas akan semakin meningkatkan komitmen dan visi universitas dalam konteks keberlanjutan.

2. Bagi pemangku kepentingan universitas

Peneliti menyadari bahwa proses implementasi akuntansi keberlanjutan di lingkungan Universitas Pendidikan Ganesha memerlukan dukungan dari pihak luar, yaitu dukungan dari seluruh pemangku kepentingan universitas. Harus terdapat sinergi antara universitas dengan seluruh pemangku kepentingan universitas agar proses implementasi konsep akuntansi keberlanjutan mendapat dukungan yang besar. Para pemangku kepentingan universitas dapat melakukan monitoring terkait dengan kinerja keberlanjutan universitas di masa depan. Proses monitoring ini tidak hanya untuk memastikan bahwa konsep keberlanjutan telah dijalankan di dalam universitas, tetapi juga untuk meningkatkan hubungan yang positif antara kepentingan universitas dengan kepentingan kelompok pemangku kepentingan universitas. Proses monitoring oleh pemangku kepentingan universitas sangat diperlukan untuk menjaga dan mengawasi agar seluruh kebijakan dan aktivitas yang dilakukan di dalam universitas telah sejalan dan selaras dengan tujuan universitas. Dengan adanya pemahaman ini, maka seluruh pemangku kepentingan universitas memiliki tanggung jawab yang besar untuk membantu tercapainya tujuan universitas.

3. Bagi penyusun dan pembuat kebijakan

Saat ini isu mengenai penerapan konsep keberlanjutan tidak lagi menjadi kepedulian di ranah bisnis dan perusahaan. Semua organisasi, baik organisasi bisnis dan organisasi non-bisnis, memiliki tanggung jawab dan kesempatan yang sama untuk menerapkan konsep keberlanjutan di dalam aktivitas organisasi. Salah satu hal atau faktor yang dapat mendorong organisasi untuk menerapkan konsep akuntansi keberlanjutan adalah adanya standar, pedoman, atau panduan. Standar, pedoman, atau panduan ini dapat menjadi rujukan atau referensi bagi organisasi yang ingin menerapkan akuntansi keberlanjutan.

\section{DAFTAR PUSTAKA}

Adams, C. A. (2013). Sustainability Reporting and Performance Management in Universities: Challenges and Benefits. Sustainability Accounting, Management and Policy Journal. https://doi.org/10.1108/SAMPJ-12-2012-0044 
Adams, C. A., Muir, S., \& Hoque, Z. (2014). Measurement of Sustainability Performance in the Public Sector. Sustainability Accounting, Management and Policy Journal. https://doi.org/10.1108/SAMPJ-04-2012-0018

Amran, A., \& Keat Ooi, S. (2014). Sustainability Reporting: Meeting Stakeholder Demands. Strategic Direction, Vol. 30(No. 7), Hal 38-41. https://doi.org/10.1108/SD-03-2014-0035

An, Y., Davey, H., Harun, H., An, Y., Davey, H., \& Harun, H. (2017). Sustainability Reporting at a New Zealand Public University: A Longitudinal Analysis. Sustainability, Vol. 9(No. 9), Hal 1529. https://doi.org/10.3390/su9091529

Botes, V., Low, M., \& Chapman, J. (2014). Is Accounting Education Sufficiently Sustainable? Sustainability Accounting, Management and Policy Journal. https://doi.org/10.1108/SAMPJ-11-2012-0041

Bradford, M., Earp, J. B., Showalter, D. S., \& Williams, P. F. (2016). Corporate Sustainability Reporting and Stakeholder Concerns: Is There A Disconnect? Accounting Horizons, Vol. 31(No. 1), Hal 83-102.

Ceulemans, K., Molderez, I., \& Van Liedekerke, L. (2015). Sustainability Reporting in Higher Education: A Comprehensive Review of the Recent Literature and Paths for Further Research. Journal of Cleaner Production, Vol.106, Hal 127143. https:// doi.org/10.1016/J.JCLEPRO.2014.09.052

Domingues, A. R., Lozano, R., Ceulemans, K., \& Ramos, T. B. (2017). Sustainability Reporting in Public Sector Organisations: Exploring the Relation between the Reporting Process and Organisational Change Management for Sustainability. Journal of Environmental Management, Vol. 192, Hal 292-301. https://doi.org/10.1016/j.jenvman.2017.01.074

Farneti, F., \& Guthrie, J. (2009). Sustainability Reporting by Australian Public Sector Organisations: Why They Report. Accounting Forum. https://doi.org/10.1016/j.accfor.2009.04.002

Kaur, A., \& Lodhia, S. (2018). Stakeholder Engagement in Sustainability Accounting and Reporting. Accounting, Auditing \& Accountability Journal, Vol. 31(No. 1), Hal 338-368. https://doi.org/10.1108/AAAJ-12-2014-1901

Lamberton, G. (2005). Sustainability Accounting-A Brief History and Conceptual Framework. Accounting Forum, Vol. 29(No. 1), Hal 7-26. https://doi.org/10.1016/j.accfor.2004.11.001

Lange, E. A., \& Kerr, S. G. (2013). Accounting and Incentives for Sustainability in Higher Education: An Interdisciplinary Analysis of A Needed Revolution. Social Responsibility Journal. https://doi.org/10.1108/SRJ-08-2011-0058

Lozano, R. (2006). A Tool for A Graphical Assessment of Sustainability in Universities (GASU). Journal of Cleaner Production, Vol. 14(No. 9-11), Hal 963972. https://doi.org/10.1016/J.JCLEPRO.2005.11.041

McNicholas, P. A., Fahmi, F. M., \& Adams, C. (2016). Sustainability Accounting in Public Sector Organizational Change Processes. Retrieved from https://research.monash.edu/en/publications/sustainability-accountingin-public-sector-organizational-change-

Nickie Petcharat, N., \& Mula, J. M. (2012). Towards a Conceptual Design for Environmental and Social Cost Identification and Measurement System. Journal of Financial Reporting and Accounting, Vol. 10(No. 1), Hal 34-54. https://doi.org/10.1108/19852511211237435

O’Dochartaigh, A. (2017). Stakeholder Relationships, Engagement, and Sustainability Reporting. Social and Environmental Accountability Journal, 
Vol.

37(No.

3),

https://doi.org/10.1080/0969160X.2017.1376909

Owen, G. (2013). Integrated Reporting: A Review of Developments and their Implications for the Accounting Curriculum. Accounting Education. https://doi.org/10.1080/09639284.2013.817798

Richardson, A. J., \& Kachler, M. D. (2016). University Sustainability Reporting: A Review of the Literature and Development of a Model. In Handbook on sustainability in management education. University of Windsor.

SIGMA Project. (2003). The sigma guidelines - toolkit (sustainability accounting guide). London: SIGMA Project. 